\title{
Performance of 2 Commercial Serologic Tests for Diagnosing Zika Virus Infection
}

\author{
Séverine Matheus, Cheikh Talla, Bhety Labeau, Franck de Laval, \\ Sébastien Briolant, Lena Berthelot, Muriel Vray, Dominique Rousset
}

\begin{abstract}
Reliable serologic tests are needed for diagnosis and surveillance of Zika virus infection. We evaluated the Euroimmun and Dia.Pro serologic tests for detection of Zika virus IgM and IgG by using a panel of 199 samples from a region endemic for flaviviruses. Kinetics of Zika virus antibodies were monitored from 300 sequential specimens sampled over a period of 10 months after infection. We observed suboptimal performance; sensitivity for Zika virus IgM was low, especially in the Euroimmun assay (49\%), whereas IgM could be detected for months with the Dia.pro assay. The specificity of the Zika virus $\lg$ assays was also low, especially that of Dia.Pro (62\%); findings were strongly influenced by the epidemiologic context. These results highlight the complexity of serologic diagnosis of Zika virus infection in regions endemic for flaviviruses. Accurate analysis of the performance of assays is required to adapt and interpret algorithms.
\end{abstract}

$\mathrm{Z}$ ika virus belongs to the Flaviviridae family, genus Flavivirus, and is an arbovirus transmitted mainly by mosquitoes of the genus Aedes (Stegomyia). Initially isolated in 1947 from a sentinel monkey during yellow fever surveillance in Uganda, Zika virus was reported as causing only sporadic human infections, associated with asymptomatic or mild, self-limiting illness, until 2007 (1,2). In 2007, Zika virus spread first to Pacific islands and then throughout the Americas, resulting in large outbreaks in several regions of the world. Zika virus infection is estimated to be symptomatic in $18 \%-73 \%$ of cases (3-5); severe complications have been reported, including neurologic disorders, such as Guillain-Barré syndrome, and congenital Zika virus syndrome, which is characterized by severe microcephaly,

Author affiliations: Institut Pasteur de la Guyane, Cayenne, French Guiana (S. Matheus, B. Labeau, L. Berthelot, D. Rousset); Institut Pasteur de Dakar, Dakar, Senegal (C. Talla, M. Vray); French Armed Forces Health Service in French Guiana, Cayenne (F. de Laval); French Military Centre for Epidemiology and Public Health, Marseille, France (F. de Laval); Institut de Recherche Biomédicale des Armées, Marseille (S. Briolant); Aix Marseille Université, Marseille (S. Briolant)

DOI: https://doi.org/10.3201/eid2506.180361 brain and ocular anomalies, congenital contractures, and neurologic impairment in the fetuses and newborns of mothers infected during pregnancy $(3,4,6)$.

The mild signs and symptoms of Zika virus infection include fever, rash, joint pain, conjunctivitis, headache, and myalgia (7). These manifestations are difficult to distinguish clinically from those caused by other arboviral infections, such as dengue or chikungunya, which are often observed in the same geographic areas. Therefore, specific, reliable diagnostic tools are needed.

Several commercial kits are available for direct viral detection by nucleic acid-based testing, which enable diagnosis during the acute phase of the disease $(8,9)$ : up to 7 days after symptom onset in serum samples, up to 20 days in urine, and even longer in semen (10-13). This virologic window, combined with the high proportion of asymptomatic forms, makes the monitoring of Zika virus infection difficult, especially in pregnant women. Therefore, serologic tools for diagnosis of Zika virus infection are urgently needed. This challenge remains because of cross-reactivity among flaviviruses, especially in a context of secondary flavivirus infection or previous immunization.

The first objective of this study was to evaluate the performance of two commercial serologic kits for the detection of Zika virus-specific IgM and IgG in serum samples from patients with an arboviral-like syndrome in a region where other arboviruses are known to circulate, including dengue and chikungunya viruses. The 2 commercial kits (4 assays) studied were the Euroimmun Zika virus IgM and IgG ELISAs (https://www.euroimmun.com) and Dia.Pro Zika virus IgM and IgG ELISAs (Diagnostic Bioprobes Srl, https:/www.diapro.it). The second objective was to determine the kinetics of Zika virus IgM and IgG induced after infection, as defined by these kits.

\section{Material and Methods}

\section{Clinical Samples and Study Design}

The clinical samples used in this study were selected according to the standards for reporting diagnostic accuracy 
requirements. Two thirds came from the serum collection of the National Reference Centre (NRC) for Arboviruses in French Guiana and one third from samples collected for a descriptive prospective study of Zika virus disease in the French military community in French Guiana (ZIFAG) (14). The NRC collection comprises clinical specimens received during 2002-2017 for routine diagnosis and expertise. The protocol of the ZIFAG study received ethics approval from the Comité de Protection des Personnes Sud-Méditerranée I (ID RCB: 2016-A00394-47); all participants provided written informed consent. All the selected specimens were obtained from patients with an arboviral-like syndrome and an etiologic diagnosis confirmed by real-time reverse transcription PCR (RTPCR) on acute-phase serum or urine samples. A commercial qualitative RT-PCR kit (Altona Diagnostics, https:// www.altona-diagnostics.com) was used for Zika virus detection and NRC in-house real-time RT-PCR for dengue and chikungunya viruses.

We first evaluated the performance of the 2 commercial immunoassays against a panel of 199 serum samples collected from days 3 through 20 after the onset of symptoms (onset defined as day 0 - that is, within the first 24 hours) (Table 1). We evaluated the sensitivity of the assays in a subgroup of 90 serum samples from 90 patients with confirmed Zika virus infection diagnosed from the end of 2015 through 2016, during the outbreak in French Guiana (Zika subgroup). We evaluated the specificity of the assays in a subgroup of 109 serum samples with a strong potential for causing flavivirus cross-reactions (non-Zika subgroup). This subgroup comprised serum samples obtained from 35 patients with confirmed dengue virus infection sampled during 2002-2013 dengue epidemics; 29 patients with confirmed chikungunya virus infection sampled during the chikungunya outbreak in French Guiana in 2014-2015, just after the dengue outbreak in 2012-2013; and 45 patients with neither dengue virus, chikungunya virus, nor Zika virus infection sampled just before the Zika virus outbreak. We peformed Zika microneutralization tests on the Zika virus, dengue virus, and chikungunya virus-negative subgroup of serum samples, enabling confirmation of the absence of Zika neutralizing antibodies.

To determine the kinetics of Zika virus antibodies, we used a panel of 300 serum samples collected from 124 patients with confirmed Zika virus infection from day 0 through day 300 after the onset of symptoms (Table 1). We collected 1-8 samples from each Zika virus-infected patient. The distribution of samples according to time since onset was as follows: 76 samples collected during days $0-4,50$ during days $5-14,55$ during days $15-30,19$ during days $31-60,32$ during days $61-90,44$ during days 91-180, and 24 during days 181-300.

\section{Euroimmun and Dia.Pro Zika Virus IgM and IgG ELISAs}

We tested all samples with the Euroimmun ELISAs according to the manufacturer's recommendations and calculated signal-to-cutoff $(\mathrm{S} / \mathrm{CO})$ ratios; values $<0.8$ were regarded as negative, $\geq 0.8$ to $<1.1$ as equivocal, and $\geq 1.1$ as positive. We tested all serum specimens with the respective Dia.Pro ELISAs for qualitative determination of IgM and IgG, according to the manufacturer's instructions; we interpreted results as positive if the $\mathrm{S} / \mathrm{CO}$ ratio was $\geq 1.1$, negative if $<0.9$, and equivocal if $0.9-1.1$. Recombinant Zika virus nonstructural protein 1 was the antigen in both the Euroimmun and Dia.Pro assays.

\section{Statistical Analysis}

Continuous variables were expressed as mean $( \pm \mathrm{SD})$ or median with interquartile range (IQR) and discrete variables as percentages and $95 \%$ CIs. We calculated the sensitivity and specificity of the assays with $95 \%$ CIs. The differences in the $\mathrm{S} / \mathrm{CO}$ ratios of the IgM and IgG assays at each time were compared with the Student $t$ test. We performed all statistical analyses using R 3.4 statistical software (https://www.r-project.org).

\begin{tabular}{|c|c|c|c|}
\hline Panel & Sample characterization & $\begin{array}{c}\text { No. } \\
\text { samples }\end{array}$ & $\begin{array}{l}\text { Mean time to collection after } \\
\text { onset of fever, } d(+S D)\end{array}$ \\
\hline \multicolumn{4}{|c|}{ Panel performance evaluation 3-20 days after onset } \\
\hline Zika virus subgroup & Positive Zika virus & 90 & $10+6$ \\
\hline \multirow[t]{3}{*}{ Non-Zika virus subgroup } & $\begin{array}{c}\text { Negative Zika virus with confirmed dengue } \\
\text { virus infection }\end{array}$ & 35 & $10 \pm 3$ \\
\hline & $\begin{array}{l}\text { Negative Zika virus with confirmed } \\
\text { chikungunya virus infection }\end{array}$ & 29 & $13 \pm 3$ \\
\hline & $\begin{array}{l}\text { Negative Zika virus, dengue virus, } \\
\text { chikungunya virus }\end{array}$ & 45 & $11 \pm 5$ \\
\hline Total panel performance & & 199 & $10+5$ \\
\hline \multicolumn{4}{|c|}{ Panel lgM-IgG kinetics $0-300$ days after onset } \\
\hline Positive Zika virus & & $300^{*}$ & $\begin{array}{c}\text { Minimum 0, maximum } 300, \\
\text { median } 20, \\
\text { interquartile range } 4-81\end{array}$ \\
\hline
\end{tabular}

\footnotetext{
*300 samples from 124 patients, including the 90 positive Zika virus samples in the first panel.
} 


\section{Results}

\section{Patient Characteristics}

The 199 samples used to evaluate the performance of the serologic kits came from patients with a mean \pm SD age of $36 \pm 16$ years (range $1-74$ years; IQR 27-46 years). This panel was composed of the Zika virus-positive subgroup $(\mathrm{n}=90), 51(57 \%)$ female and $39(43 \%)$ male, with a mean age \pm SD of $39 \pm 12$ years; and the Zika virus-negative subgroup $(\mathrm{n}=109), 62(57 \%)$ female and $45(43 \%)$ male, with a mean \pm SD age of $34 \pm 18$ years (Table 1).

The 300 samples used to determine the kinetics of Zika virus IgM and IgG came from 124 patients, 82 (66\%) female and $42(34 \%)$ male. The age range of these patients was $8-74$ years (mean \pm SD $37 \pm 11$ years).

\section{Performance of Zika Virus IgM ELISAs}

We evaluated the sensitivity and specificity of the 2 Zika virus IgM tests against 90 Zika virus subgroup samples and 109 non-Zika subgroup samples (Table 2). Each test gave inconclusive results for 6 of the 199 samples: with the Euroimmun test, we obtained 6 inconclusive results from the 90 samples from the Zika virus subgroup, and with the Dia.Pro test, we obtained 4 inconclusive results of the 90 samples from the Zika virus subgroup and 2 for samples collected on day 9 after onset of disease from patients with confirmed dengue virus infection.

The sensitivity of the Euroimmun Zika virus IgM test was $49 \%(41 / 84 ; 95 \%$ CI $38 \%-60 \%)$; sensitivity of the Dia.Pro test was $69 \%$ (59/86; 95\% CI 59\%-79\%). Only 1 of the 109 non-Zika subgroup serum samples was positive in the Euroimmun test, indicating $99 \%$ specificity $(95 \%$ CI $97 \%-100 \%$ ). Four non-Zika subgroup samples were detected as positive by the Dia.Pro IgM test, including 3 samples from patients with acute dengue virus infection, indicating a specificity of $96 \%(103 / 107 ; 95 \%$ CI $92 \%-100 \%$ ).

\section{Performance of Zika Virus IgG ELISAs}

We used the same panel to evaluate the performance of Euroimmun and Dia.Pro Zika virus IgG kits (Table 2). With the Euroimmun test, $16(8 \%)$ of the 199 samples gave inconclusive results, 8 among positive Zika virus samples collected on days 5 ( 1 sample) and 9 (7 samples) of disease onset; 8 negative Zika virus samples also gave inconclusive results ( 5 chikungunya virus-positive samples and 3 from the group negative for dengue virus, chikungunya virus, and Zika virus). The sensitivity of this assay was $71 \%(58 / 82 ; 95 \%$ CI $92 \%-100 \%)$ and the specificity $70 \%$ (71/101; 95\% CI 61\%-79\%). With the Dia.Pro IgG test, 8 samples gave inconclusive results: 5 samples from the Zika virus-positive group ( 2 collected before day 5 and the others on day 9 or later after the onset of illness) and 3 samples from the Zika virus-negative group (collected on days 4 to 6 after onset) (Table 2). The sensitivity of this assay was $79 \%(67 / 85 ; 95 \%$ CI $70 \%-88 \%)$ and the specificity $62 \%$ (66/106; 95\% CI 53\%-71\%).

The false positivity rate of the 2 Zika virus IgG assays varied according to the subpanel used. These rates were $40 \%-58.6 \%$ for positive dengue virus or chikungunya virus sample subgroups and $11.9 \%-21.4 \%$ for the negative dengue virus, negative chikungunya virus, and negative Zika virus sample subgroup (Table 3 ).

\begin{tabular}{|c|c|c|c|c|c|c|c|}
\hline \multirow[b]{2}{*}{ Results } & \multirow[b]{2}{*}{$\begin{array}{c}\text { Zika } \\
\text { subgroup }\end{array}$} & \multicolumn{4}{|c|}{ Non-Zika subgroup } & \multirow[b]{2}{*}{ Total } & \multirow[b]{2}{*}{$\begin{array}{l}\text { Sensitivity }(95 \% \mathrm{Cl}) \text {, } \\
\text { specificity }(95 \% \mathrm{Cl})\end{array}$} \\
\hline & & All & Zika-/DENV+ & Zika-/CHIKV+ & $\begin{array}{l}\text { Zika-/DENV- } \\
\text { /CHIKV- }\end{array}$ & & \\
\hline \multicolumn{8}{|c|}{ Euroimmun lgM test } \\
\hline Positive & 41 & 1 & 0 & 0 & 1 & 42 & $49 \%$ (38-60), 99\% \\
\hline Negative & 43 & 108 & 35 & 29 & 44 & 151 & $(97-100)$ \\
\hline Inconclusive & 6 & 0 & 0 & 0 & 0 & 6 & \\
\hline Total & 90 & 109 & 35 & 29 & 45 & 199 & \\
\hline \multicolumn{8}{|l|}{ Dia.Pro lgM test } \\
\hline Positive & 59 & 4 & 3 & 1 & 0 & 63 & $69 \%$ (59-79), 96\% \\
\hline Negative & 27 & 103 & 30 & 28 & 45 & 130 & $(92-100)$ \\
\hline Inconclusive & 4 & 2 & 2 & 0 & 0 & 6 & \\
\hline Total & 90 & 109 & 35 & 29 & 45 & 199 & \\
\hline \multicolumn{8}{|c|}{ Euroimmun IgG test } \\
\hline Positive & 58 & 30 & 14 & 11 & 5 & 88 & $71 \%(61-81), 70 \%$ \\
\hline Negative & 24 & 71 & 21 & 13 & 37 & 95 & $(61-79)$ \\
\hline Inconclusive & 8 & 8 & 0 & 5 & 3 & 16 & \\
\hline Total & 90 & 109 & 35 & 29 & 45 & 199 & \\
\hline \multicolumn{8}{|l|}{ Dia.Pro lgG test } \\
\hline Positive & 67 & 40 & 14 & 17 & 9 & 107 & $79 \%$ (70-88), 62\% \\
\hline Negative & 18 & 66 & 21 & 12 & 33 & 84 & $(53-71)$ \\
\hline Inconclusive & 5 & 3 & 0 & 0 & 3 & 8 & \\
\hline Total & 90 & 109 & 35 & 29 & 45 & 199 & \\
\hline
\end{tabular}

${ }^{*} \mathrm{CHIKV}$, chikungunya virus; DENV, dengue virus; +, positive; -, negative. 
Table 3. Rate and ratio of false Zika virus IgG-positive samples obtained with Euroimmun and Dia.Pro Zika virus IgG assays according to the non-Zika virus sample subgroup

\begin{tabular}{lccc}
\hline & $\begin{array}{c}\text { Positive for } \\
\text { dengue virus, } \\
\text { collected before 2013 }\end{array}$ & $\begin{array}{c}\text { Positive for } \\
\text { chikungunya virus, } \\
\text { collected in 2014 }\end{array}$ & $\begin{array}{c}\text { Negative for Zika, dengue, and } \\
\text { chikungunya viruses, } \\
\text { collected at end of 2015 }\end{array}$ \\
\hline Test & & & \\
Euroimmun IgG test & $40 \%(14 / 35)$ & $45.8 \%(11 / 24)$ & $11.9 \%(5 / 42)$ \\
$\quad$ False positivity rate, \% (pos/pos + neg) & $3.9(1.1-6.7)$ & $2.0(1.2-2.9)$ & $2.0(1.3-3.7)$ \\
$\quad$ IgG S/C ratio of false-positive IgG, mean (range) & & & \\
\hline Dia.Pro IgG test & $40 \%(14 / 35)$ & $58.6 \%(17 / 29)$ & $21.4 \%(9 / 42)$ \\
$\quad$ False positivity rate, \% (pos/pos + neg) & $9.2(2.5-14.4)$ & $3.1(1.1-7.7)$ & $4.3(1.1-10.1)$ \\
$\quad$ IgG S/C ratio of false-positive IgG, mean (range) & & & \\
\hline${ }^{*}$ Neg, negative; pos, positive. & & \\
\hline
\end{tabular}

\section{Performance of Combined IgM/lgG Assays}

The sensitivity of the combined Euroimmun Zika virus IgM and $\mathrm{IgG}$ assays was $82 \%(71 / 87 ; 95 \%$ CI $74 \%-90 \%)$ and the specificity was $69 \%(70 / 101 ; 95 \%$ CI 60\%-78\%). The sensitivity of the combined Dia.Pro Zika virus IgM and IgG assays was $87 \%(75 / 86 ; 95 \%$ CI $80 \%-94 \%)$ and specificity was $62 \%$ (66/106; 95\% CI 53\%-71\%).

\section{Time-Course Analysis of Zika Virus IgM and IgG, Days 0-300 after Onset of Symptoms}

We used the panel of sequential samples from patients with confirmed Zika virus infection to determine the kinetics of Zika virus IgM and IgG over 10 months after clinical onset (Figure 1). For the Euroimmun Zika virus IgM test, maximum percentage detection $(71 \%)$ was $15-30$ days after the onset of disease. After this time, the percentage of detectable IgM decreased rapidly, to only $21 \%$ of samples collected in days 31-60 and $<9 \%$ for those collected $>60$ days after infection (Figure 1, panel A). The Dia.Pro Zika virus IgM test was more sensitive, with higher rates of positive samples observed over a longer time: $29 \%$ positive samples on days 0-4 after clinical onset, increasing to a maximum of $93 \%$ positivity during days $15-30$. The positivity rate decreased more slowly than with the Euroimmun test, and $29 \%$ of samples were still positive for IgM during days 181-300 after infection. For Zika virus $\mathrm{IgG}$, both assays detected the antibody in $>40 \%$ of samples collected during the acute phase of disease (days $0-4$ ) and in $100 \%$ of samples collected during days $31-$ 180 after onset of disease (Figure 1, panel B). A slight decrease in the positivity rate for $\operatorname{IgG}$ observed with the Euroimmun assay before day 300 suggests a possible lack of sensitivity over time.

We also evaluated the evolution of the overall mean $\mathrm{S} /$ $\mathrm{CO}$ ratios by time and the test used (Figure 1, panels $\mathrm{C}$ and D). We observed similar kinetics for the mean $\mathrm{S} / \mathrm{CO}$ ratios
A

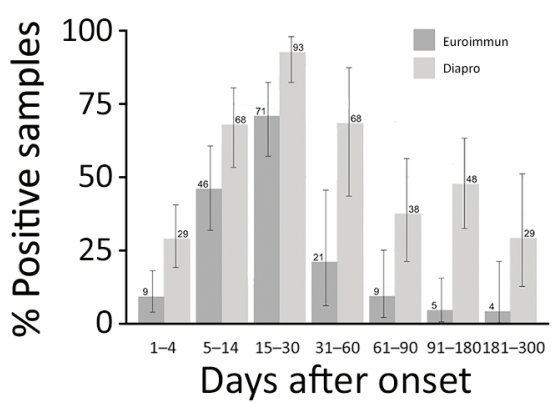

C

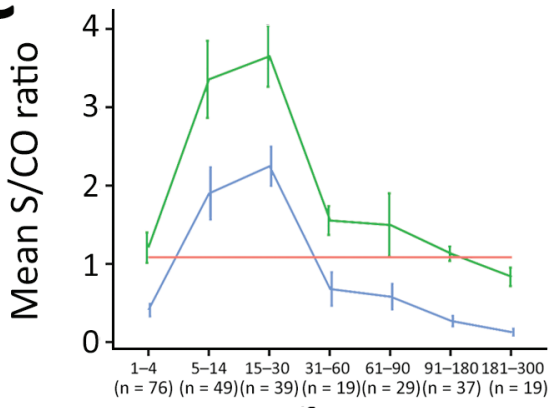

Days after onset
B

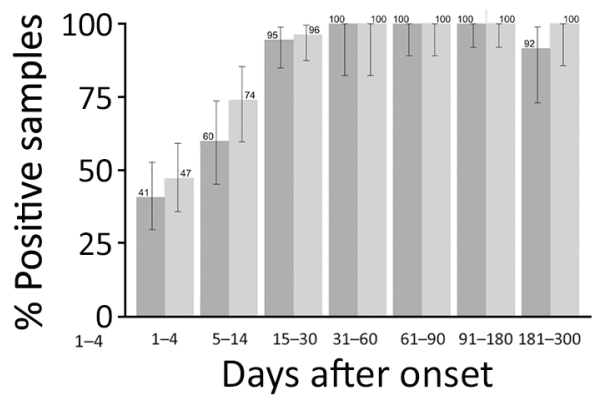

D

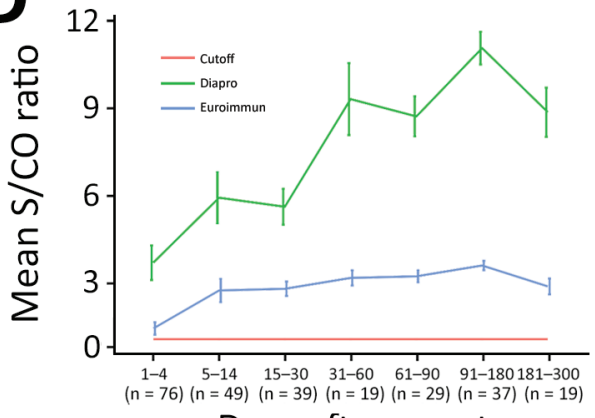

Days after onset
Figure 1. Kinetics of Zika virus $\operatorname{lgM}$ and $\lg \mathrm{G}$ as determined with Euroimmun and Dia.Pro kits for patient samples collected in the first 10 months after infection, by time interval. A, B) Percent positive for Zika virus $\lg M(A)$ and $\lg G(B)$. Values are given with binomial proportion Cl). C, D) Overall time course of mean signal-to-cutoff ratios of Zika virus $\lg M(C)$ and $\lg G(D)$. Values are shown with SEs. The number of patients sampled is provided for each time interval. 
for the 2 assays: the maximum mean $\mathrm{S} / \mathrm{CO}$ ratio peaked during days $15-31$ for the IgM assays and during days 91-180 for the IgG assays. Nevertheless, the differences between the mean $\mathrm{S} / \mathrm{CO}$ ratios for both the IgM and the IgG assays at each time after infection class were significant (all $\mathrm{p}<0.05$ )
(Figure 1, panels C and D). The Dia.Pro assays gave higher $\mathrm{S} / \mathrm{CO}$ ratios for the same threshold values, explaining the greater sensitivity of these tests. We obtained the kinetics of Zika virus IgM and IgG with both assays for patients for whom we had $\geq 5$ sequential samples (Figure 2 ).
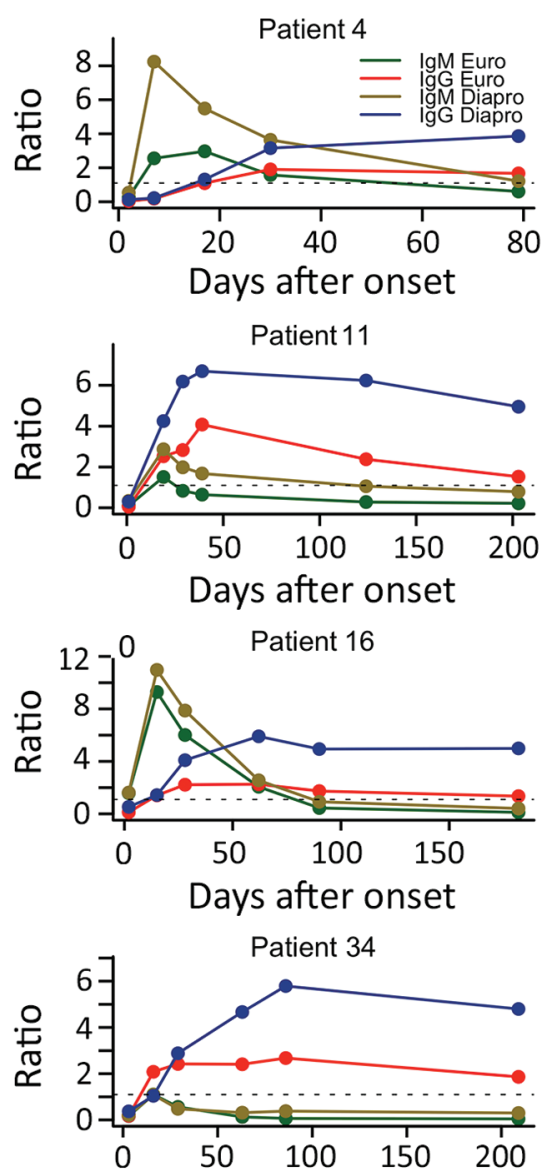

Days after onset
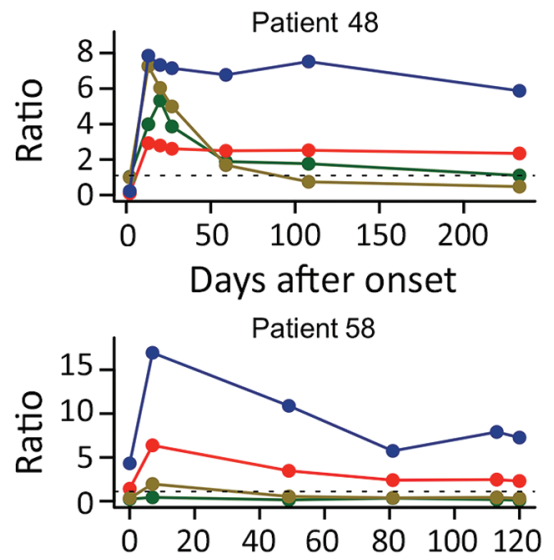

Days after onset
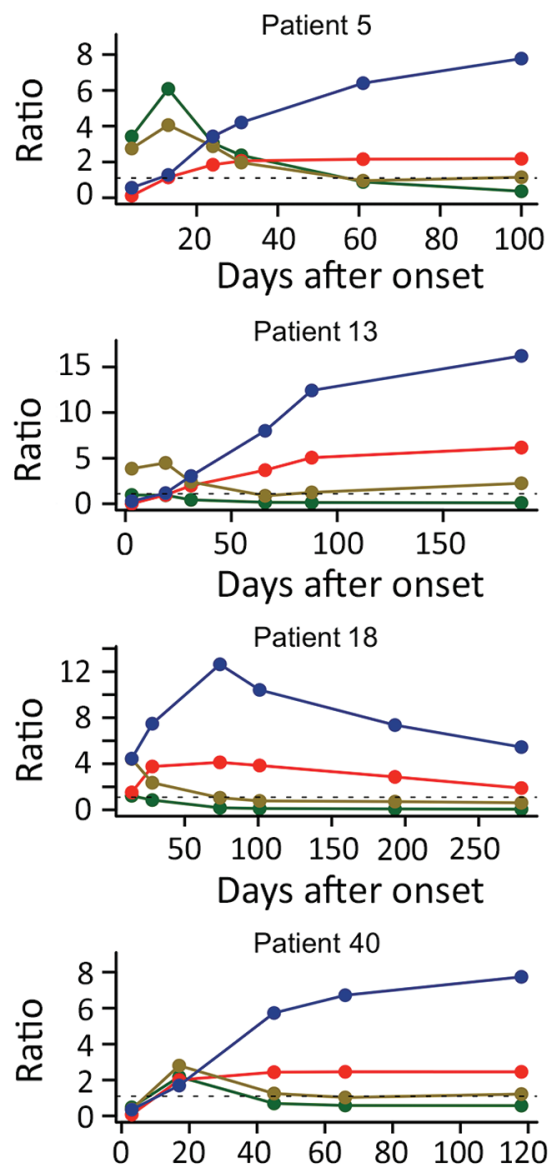

Days after onset

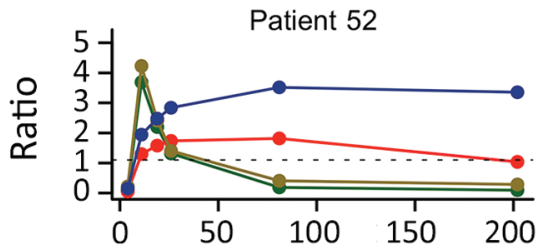

Days after onset

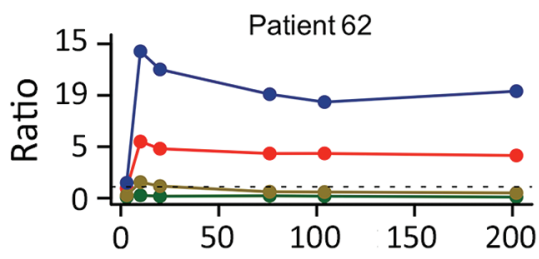

Days after onset
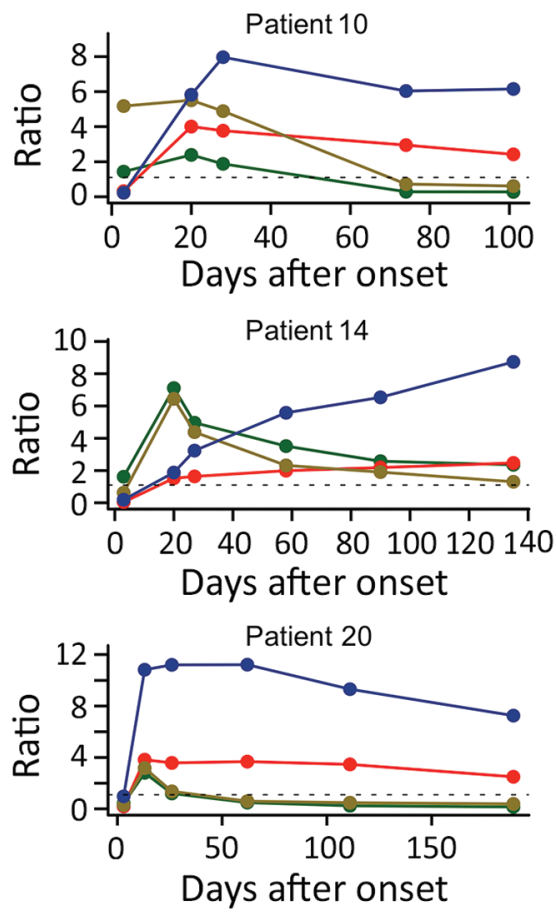

Patient 41

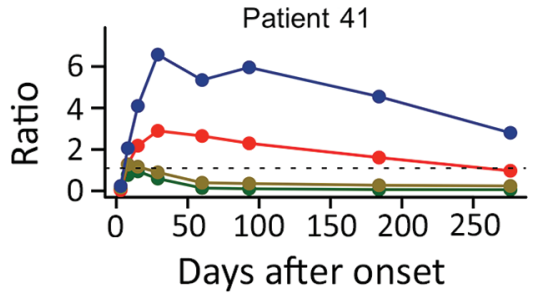

Patient 53
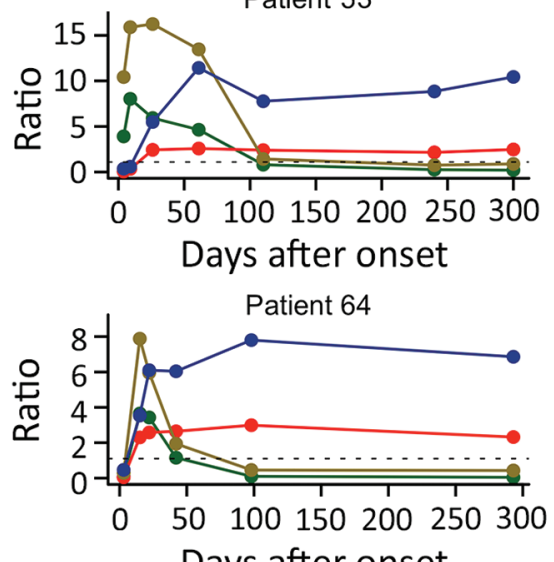

Figure 2. Individual time-course analyses of Zika virus IgM and IgG signal-to-cutoff ratios obtained by using Euroimmun and Dia.Pro kits for 18 patients for whom 5 or more sequential samples were available. 


\section{Discussion}

In this assessment of the performance of Euroimmun and Dia.Pro Zika virus IgM and IgG ELISAs for diagnosis of Zika virus infection, we had a large panel of well-characterized samples from areas endemic for arboviruses, the dates of symptom onset, and infection confirmed by realtime RT-PCR. Although the Dia.Pro IgM assay was more sensitive (69\%) than the Euroimmun IgM test (49\%), the performance of both IgM assays was suboptimal. The sensitivity of a screening test is a major factor in determining its usefulness, because poor sensitivity of the first test used in a diagnostic algorithm could lead to false-negative results that would not be further evaluated.

The sensitivity of the Euroimmun Zika virus IgM test was significantly lower than that reported previously (15-18). The differences might be caused by differences in study design, selection criteria, and the few positive samples in the previous studies (17-18). The lower sensitivity we found for this assay might also be the result of the larger proportion of secondary flavivirus infections in the panel used, as the samples were taken in an area endemic-epidemic for dengue and with mandatory vaccination against yellow fever. A significant lower sensitivity of the Euroimmun Zika virus IgM assay has also been reported in travelers from Israel compared with travelers from Europe and Chile, possibly related to the West Nile virus background immunity of the population of Israel (19). More recent evaluations have also reported low sensitivity $(39.5 \%$ and $37 \%)$ of the Euroimmun assays $(20,21)$.

Sensitivity is essential for a frontline diagnostic test, and specificity should also be carefully evaluated. In our study, we assessed the specificity of all the tests with various non-Zika virus samples to evaluate potential crossreactivity. A first subpanel of samples from patients with confirmed acute dengue virus infection was formed because of the high potential for flavivirus cross-reactivity; a second subpanel consisted of samples from patients with confirmed chikungunya virus infection; and a third subpanel consisted of samples from patients with no dengue virus, chikungunya virus, or Zika virus infection. The specificity of the Euroimmun Zika virus IgM assay was $99 \%$ and that of the Dia.Pro test was $96 \%$, with cross-reactivity varying according to the subpanel. Most cross-reactions were observed in the subpanel of acute dengue samples, in which 3 of 33 samples were false positive for Zika virus IgM, whereas 1 of 74 samples collected $>1$ year after the dengue epidemic (chikungunya virus subpanel and dengue virus, chikungunya virus, and Zika virus negative subpanel) was false positive. Maximum cross-reactivity of IgG tests was seen in the subpanel collected in the post-dengue epidemic period in 2014-2015. The false-positivity rate was $40 \%$ $(14 / 35)$ in the acute dengue subpanel for both commercial tests; the rate grew to $45.8 \%(11 / 24)$ for the Euroimmun
Zika virus IgG test and 58.6\% (17/29) for the Dia.Pro Zika virus $\operatorname{IgG}$ test in the subpanel of acute chikungunya virus samples collected right after the dengue epidemic period in 2014-2015. The IgG cross-reactions tended to decrease with time: 2 years after the end of the latest dengue epidemic in French Guiana, 5/42 (11.9\%) samples were falsely positive by the Euroimmun IgG test and 9/42 (21.4\%) samples were falsely positive with the Dia.Pro test. All samples except 2 with a false-positive result for Zika virus IgG were positive for dengue virus IgG by our in-house IgG antibody capture ELISA technique. The predictive positive value of both Zika virus IgG assays therefore largely depends on the epidemiologic situation of other flaviviruses, like dengue virus.

A study performed in Martinique during March-June 2016 during the Zika virus epidemic showed a good correlation between a high Euroimmun Zika virus IgG ratio and a positive Zika virus seroneutralization result. Ratios $>4$ were associated with positive seroneutralization in $>95 \%$ of cases, whereas ratios $>5$ were associated with seroneutralization in $100 \%$ of cases (22). At the time of the study, only sporadic dengue cases were reported in Martinique, as the previous epidemic occurred in 2013-2014, >2 years earlier. In our assessment, the IgG S/C ratio value of false Zika virus IgG-positive samples varied from 1.1 to 6.7 (mean 3.9) for acute dengue samples to 1.2 to 3.7 (mean 2.0) for other non-Zika virus samples. These results underline the importance and potential efficacy of using selected panels to evaluate performance and, especially, the specificity of serologic assays. These results also indicate that when there is major cocirculation of dengue virus and Zika virus, the interpretation of serologic assays could be increasingly complex.

The overall specificity of the Euroimmun Zika virus IgG assay was $79 \%$ and that of the Dia.Pro assay was $62 \%$. These results indicate suboptimal specificity, which is lower than that reported previously $(20,21)$, and is a concern for serologic diagnosis of Zika virus infection. Seroneutralization is the classical reference test for confirming contact with Zika virus in cases of positive results with ELISA assays in regions where flaviviruses cocirculate; however, even seroneutralization tests could be difficult to interpret, leading the US Centers for Disease Control and Prevention to change its guidance for interpretation of Zika virus antibody test results in May $2016(23,24)$. In cases of secondary flavivirus infection, a microneutralization test might not discriminate between the past and recent infecting viruses, leading to an assumption of just a recent flavivirus exposure.

As reported previously by others, when IgM and $\operatorname{IgG}$ results were combined, sensitivity increased to $82 \%$ for Euroimmun and $87 \%$ for Dia.Pro assays, whereas specificity decreased to $69 \%$ for Euroimmun and $62 \%$ for Dia.Pro 
Tests for Diagnosing Zika Virus Infection

$(20,21)$. However, according to this combined analysis, $42 \%(30 / 71)$ of samples positive by the Euroimmun assays and $21 \%(16 / 75)$ for the Dia.Pro assays correspond to IgM negative/IgG positive samples, for which distinction between recent and past infections is not possible. Thus, a combined interpretation is not suitable for Zika infection diagnosis in the context of endemic-epidemic circulation.

We not only assessed the performance of Euroimmun and Dia.Pro Zika virus IgM and IgG tests but also evaluated the kinetics of the antibodies through 300 days after the onset of symptoms. A major concern in serologic diagnosis of Zika virus infection is determining the date of infection, due to the high proportion of asymptomatic forms. Data on the duration of IgM persistence after Zika virus infection are still limited, but our results indicate that this antibody could persist for at least several months, as described for other arboviruses (25). Such persistence could preclude determination of the recent nature of an infection, and other assays should be evaluated. The analysis of individual Zika virus antibody kinetics revealed distinct patterns. In some patients (such as patients 4, 5, 10, 16, 53), high IgM ratios during the acute phase were associated with delayed and moderate increases in Zika virus IgG ratios, possibly reflecting a primary flavivirus or Zika virus infection; for other patients (such as patients 20,34, 41, 58, 62), an early increase in the IgG ratio was combined with a low or even negative Zika virus IgM ratio throughout follow-up, indicating secondary flavivirus infections. These 2 types of kinetics showed contrasted signal intensities, which are not observed with our in-house ELISA assays, in which whole Zika virus is used as an antigen (data not shown).

A limitation of our study is that the Zika virus-positive samples were confirmed by RT-PCR and thus were all from symptomatic cases. If antibody levels are different in symptomatic and asymptomatic infections, as described for dengue, the performance and antibody kinetics observed in this study might be considerably different in samples from asymptomatic infections $(26,27)$.

This study highlights the complexity of interpreting serologic assays in areas where various arboviruses cocirculate and demonstrates the importance of evaluating serologic assays with serum specimens from persons living in endemic-epidemic areas and use of parallel testing antibodies to maximize the reliability of diagnosis. Further studies are also needed to identify specific biomarkers of each flavivirus infection for diagnosis after the acute phase of disease.

This study was supported by Institut Pasteur de la Guyane and Santé Publique France (Saint-Maurice, France) and received assistance from Investissement d'Avenir grants managed by the French Agence Nationale de la Recherche (CEBA ANR10-LABEX-25-01).

\section{About the Author}

Dr. Matheus is a research assistant at the Institut Pasteur de la Guyane, Cayenne, French Guiana. Her primary research interest is the diagnosis and pathophysiology of arboviruses.

\section{References}

1. Dick GW, Kitchen SF, Haddow AJ. Zika virus. I. Isolations and serological specificity. Trans R Soc Trop Med Hyg. 1952;46: 509-20. http://dx.doi.org/10.1016/0035-9203(52)90042-4

2. Faye O, Freire CC, Iamarino A, Faye O, de Oliveira JV, Diallo M, et al. Molecular evolution of Zika virus during its emergence in the 20th century. PLoS Negl Trop Dis. 2014;8:e2636. http://dx.doi.org/10.1371/journal.pntd.0002636

3. Duffy MR, Chen TH, Hancock WT, Powers AM, Kool JL, Lanciotti RS, et al. Zika virus outbreak on Yap Island, Federated States of Micronesia. N Engl J Med. 2009;360:2536-43. http://dx.doi.org/10.1056/NEJMoa0805715

4. Saiz JC, Martín-Acebes MA, Bueno-Marí R, Salomón OD, Villamil-Jiménez LC, Heukelbach J, et al. Zika virus: What have we learnt since the start of the recent epidemic? Front Microbiol. 2017;8:1554. http://dx.doi.org/10.3389/fmicb.2017.01554

5. de Laval F, Matheus S, Maquart M, Yvrard E, Barthes N, Combes C, et al. Prospective Zika virus disease cohort: systematic screening. Lancet. 2016;388:868. http://dx.doi.org/10.1016/ S0140-6736(16)31429-5

6. Cao-Lormeau VM, Blake A, Mons S, Lastere S, Roche C, Vanhomwegen J, et al. Guillain-Barré syndrome outbreak associated with Zika virus infection in French Polynesia: a casecontrol study. Lancet. 2016;387:1531-9. http://dx.doi.org/10.1016/ S0140-6736(16)00562-6

7. Ahmad SS, Amin TN, Ustianowski A. Zika virus: management of infection and risk. BMJ. 2016;352:i1062. http://dx.doi.org/10.1136/ bmj.i1062

8. L'Huillier AG, Lombos E, Tang E, Perusini S, Eshaghi A, Nagra S, et al. Evaluation of Altona Diagnostics RealStar Zika virus reverse transcription-PCR test kit for Zika virus PCR testing. J Clin Microbiol. 2017;55:1576-84. http://dx.doi.org/10.1128/ JCM.02153-16

9. Ölschläger S, Enfissi A, Zaruba M, Kazanji M, Rousset D. Diagnostic validation of the RealStar ${ }^{\circledR}$ Zika virus reverse transcription polymerase chain reaction kit for detection of Zika virus RNA in urine and serum specimens. Am J Trop Med Hyg. 2017;97:1070-1. http://dx.doi.org/10.4269/ajtmh.17-0268

10. Lanciotti RS, Kosoy OL, Laven JJ, Velez JO, Lambert AJ, Johnson AJ, et al. Genetic and serologic properties of Zika virus associated with an epidemic, Yap State, Micronesia, 2007. Emerg Infect Dis. 2008;14:1232-9. http://dx.doi.org/10.3201/ eid1408.080287

11. Gourinat AC, O'Connor O, Calvez E, Goarant C, Dupont-Rouzeyrol M. Detection of Zika virus in urine. Emerg Infect Dis. 2015;21:84-6. http://dx.doi.org/10.3201/eid2101.140894

12. Bingham AM, Cone M, Mock V, Heberlein-Larson L, Stanek D, Blackmore C, et al. Comparison of test results for Zika virus RNA in urine, serum, and saliva specimens from persons with travelassociated Zika virus disease-Florida, 2016. MMWR Morb Mortal Wkly Rep. 2016;65:475-8. http://dx.doi.org/10.15585/ mmwr.mm6518e2

13. de Laval F, Matheus S, Labrousse T, Enfissi A, Rousset D, Briolant S. Kinetics of Zika viral load in semen. N Engl J Med. 2017;377:697-9. http://dx.doi.org/10.1056/NEJMc1612600

14. Bossuyt PM, Reitsma JB, Bruns DE, Gatsonis CA, Glasziou PP, Irwig L, et al.; STARD Group. STARD 2015: an updated list of essential items for reporting diagnostic accuracy studies. BMJ. 2015;351:h5527. http://dx.doi.org/10.1136/bmj.h5527 
15. Steinhagen K, Probst C, Radzimski C, Schmidt-Chanasit J, Emmerich P, van Esbroeck M, et al. Serodiagnosis of Zika virus (ZIKV) infections by a novel NS1-based ELISA devoid of cross-reactivity with dengue virus antibodies: a multicohort study of assay performance, 2015 to 2016. Euro Surveill. 2016;21:30426. http://dx.doi.org/10.2807/1560-7917.ES.2016.21.50.30426

16. Pasquier C, Joguet G, Mengelle C, Chapuy-Regaud S, Pavili L, Prisant N, et al. Kinetics of anti-ZIKV antibodies after Zika infection using two commercial enzyme-linked immunoassays. Diagn Microbiol Infect Dis. 2018;90:26-30. http://dx.doi.org/ 10.1016/j.diagmicrobio.2017.09.001

17. Granger D, Hilgart H, Misner L, Christensen J, Bistodeau S, Palm J, et al. Serologic testing for Zika virus: comparison of three Zika virus IgM-screening enzyme-linked immunosorbent assays and initial laboratory experiences. J Clin Microbiol. 2017; 55:2127-36. http://dx.doi.org/10.1128/JCM.00580-17

18. Huzly D, Hanselmann I, Schmidt-Chanasit J, Panning M. High specificity of a novel Zika virus ELISA in European patients after exposure to different flaviviruses. Euro Surveill. 2016;21:30203. 10.2807/1560-7917.ES.2016.21.16.30203 http://dx.doi.org/10.2807/1560-7917.ES.2016.21.16.30203

19. Lustig Y, Zelena H, Venturi G, Van Esbroeck M, Rothe C, Perret C, et al. Sensitivity and kinetics of an NS1-based Zika virus enzymelinked immunosorbent assay in Zika virus-infected travelers from Israel, the Czech Republic, Italy, Belgium, Germany, and Chile. J Clin Microbiol. 2017;55:1894-901. 10.1128/JCM.00346-17 http://dx.doi.org/10.1128/JCM.00346-17

20. L'Huillier AG, Hamid-Allie A, Kristjanson E, Papageorgiou L, Hung S, Wong CF, et al. Evaluation of Euroimmun Anti-Zika virus IgM and IgG enzyme-linked immunosorbent assays for Zika virus serologic testing. J Clin Microbiol. 2017;55:2462-71. http://dx.doi.org/10.1128/JCM.00442-17

21. Safronetz D, Sloan A, Stein DR, Mendoza E, Barairo N, Ranadheera C, et al. Evaluation of 5 commercially available Zika virus immunoassays. Emerg Infect Dis. 2017;23:1577-80. http://dx.doi.org/10.3201/eid2309.162043

22. Gallian P, Cabié A, Richard P, Paturel L, Charrel RN, Pastorino B, et al. Zika virus in asymptomatic blood donors in Martinique. Blood. 2017;129:263-6. http://dx.doi.org/10.1182/blood2016-09-737981

23. Rabe IB, Staples JE, Villanueva J, Hummel KB, Johnson JA, Rose L, et al.; MTS. Interim guidance for interpretation of Zika virus antibody test results. MMWR Morb Mortal Wkly Rep. 2016;65:543-6. http://dx.doi.org/10.15585/mmwr.mm6521e1

24. Keasey SL, Pugh CL, Jensen SM, Smith JL, Hontz RD, Durbin AP, et al. Antibody responses to Zika virus infections in environments of flavivirus endemicity. Clin Vaccine Immunol. 2017;24 e00036-17. http://dx.doi.org/10.1128/CVI.00036-17

25. Talarmin A, Labeau B, Lelarge J, Sarthou JL. Immunoglobulin A-specific capture enzyme-linked immunosorbent assay for diagnosis of dengue fever. J Clin Microbiol. 1998;36:1189-92.

26. Yeo AS, Rathakrishnan A, Wang SM, Ponnampalavanar S, Manikam R, Sathar J, et al. Dengue patients exhibit higher levels of PrM and $\mathrm{E}$ antibodies than their asymptomatic counterparts. Biomed Res Int. 2015;2015:420867. http://dx.doi.org/10.1155/ 2015/420867

27. Simon-Lorière E, Duong V, Tawfik A, Ung S, Ly S, Casadémont I, et al. Increased adaptive immune responses and proper feedback regulation protect against clinical dengue. Sci Transl Med. 2017;9:eaal5088. http://dx.doi.org/10.1126/scitranslmed. aal5088

Address for correspondence: Dominique Rousset, Institut Pasteur de la Guyane, Laboratoire de Virologie, 23 avenue Pasteur, BP 6010, 97306 Cayenne CEDEX, French Guiana; email: drousset@pasteur-cayenne.fr

\section{EID Podcast: Probable Unusual Transmission of Zika Virus}

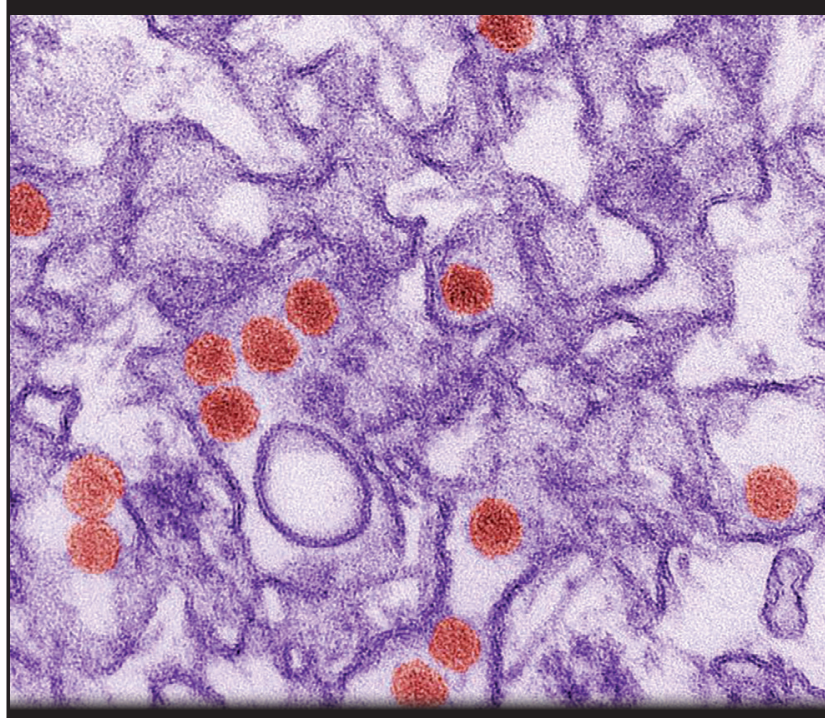

Zika virus, a mosquito-transmitted flavivirus, has been isolated from sentinel monkeys, mosquitoes, and sick persons in Africa and Southeast Asia. Serologic surveys indicate that Zika virus infections can be relatively common among persons in southeastern Senegal and other areas of Africa, but that Zika virus-associated disease may be underreported or misdiagnosed. In 2007, a large outbreak of Zika virus infection occurred on Yap Island in the southwestern Pacific that infected $\approx 70 \%$ of the island's inhabitants, which highlighted this virus as an emerging pathogen. The purpose of this study was to investigate and report 3 unusual cases of arboviral disease that occurred in Colorado in 2008.

Clinical and serologic evidence indicate that two American scientists contracted Zika virus infections while working in Senegal in 2008. One of the scientists transmitted this arbovirus to his wife after his return home. Direct contact is implicated as the transmission route, most likely as a sexually transmitted infection.

Visit our website to listen: https: / / www2c.cdc.gov/ podcasts/player.asp?f=7106489 EMERGING INFECTIOUS DISEASES 